\title{
Pivo a zdraví
}

\section{Beer And Health}

Jana OLŠOVSKÁ, Dagmar MATOULKOVÁ, Pavel ČEJKA, Marie JURKOVÁ

Výzkumný ústav pivovarský a sladařský, a. s., Pivovarský ústav Praha, Lípová 15, 12044 Praha 2 / Research Institute of Brewing and Malting, Plc., Prague Brewery Institute, Lípová 15, 12044 Prague 2

e-mail: olsovska@beerresearch.cz

Recenzovaný článek / Reviewed paper

Olšovská, J. - Matoulková, D. - Čejka, P. - Jurková, M.: Pivo a zdraví. Kvasny Prum. 60, 2014, č. 7-8, s. 174-181

Pivo je nesporně zdravý nápoj. Jeho konzumace přináší spotřebiteli mnoho benefitů, především osvěžení a relaxaci, pivo má pozitivní vliv na trávení, a je zdrojem základních nutrientů a mikronutrientů. Na základě monitoringu piva z české tržní sítě, zahrnující piva z velkých, středních a restauračních pivovarů, byla vytvořena nová studie o obsahu zdravotně pozitivních látek v pivu. Bylo potvrzeno, že česká piva obsahuji mimo jiné významné koncentrace vitamínů $B$ a některých významných fytoestrogenů. Studie dále přináší výsledky obsahu látek opačného charakteru, tedy látek toxických, vznikajících v pivu především v důsledku mikrobiologické kontaminace. Zvýšené koncentrace biogenních aminů a N-nitrosaminů byly zaznamenány v některých provozech minipivovarů a poukazují na jejich snížený hygienický stav.

Olšovská, J. - Matoulková, D. - Čejka, P. - Jurková, M.: Beer and health. Kvasny Prum. 60, 2014, No. 7-8, pp. 174-181

Beer is indisputably a healthy beverage. Its consumption brings to the consumer many benefits, especially refreshment and relaxation. Beer has a positive effect on digestion, and is a source of essential nutrients and micronutrients. Based on monitoring the Czech beer market network involving beer from large, medium and restaurant breweries, a new study was performed on the content of health-positive substances in beer. It was confirmed that Czech beer contains, among others, a significant concentration of B vitamins and some important phytoestrogens. The study also monitors the content of potentially adverse substances, i.e. substances which are toxic and get into beer mainly due to microbiological contamination. Increased concentrations of biogenic amines and N-nitrosamines have been reported in beers from some minibreweries; this points to their lower hygienic conditions.

Olšovská, J. - Matoulková, D. - Čejka, P. - Jurková, M.: Bier und Gesundheit. Kvasny Prum. 60, 2014, Nr. 7-8, S. 174-181

Bier ist ohne Zweifel ein gesundes Getränk, seine Konsumation bringt dem Verbraucher viele Benefits, vor allem Erfrischung und Relaxation, Bier wirkt positiv auf das Verdauen und ist eine Quelle von Grundnährstoffen und Mikronährstoffen. Auf dem Grund einer Monitoring des tschechischen Biermarkts mit Bieren aus großen, mittelständigen und Gaststättenbrauereien wurde eine neue Studie über einen Gehalt an gesundheitlich positiv wirkende Stoffe im Bier verfasst. Es wurde bestätigt, dass das tschechische Bier unter anderem eine bedeutende Konzentration von B-Vitaminen und einige bedeutende Phytoestrogens enthält. Weiterhin bringt die Studie Ergebnisse über den Gehalt an Stoffe des entgegengesetzten Charakters, also über toxische Stoffe, die im Bier vor allem infolge einer mikrobiologischen Kontamination entstehen. Die erhöhte Konzentration von biogenen Aminen und N-Nitrosaminen wurden in einigen Gaststättenbrauereien festgestellt, was eine niedrigere Hygiene im Betrieb aufweist.

Klíčová slova: pivo, zdraví, fytoestrogeny, vitamíny B, biogenní
aminy, $N$-nitrosaminy, ATNC, mikrobiologická kontaminace

\section{1 ÚVOD}

Pivo je důležitým zdrojem hlavních výživných (nutričních) látek, jako jsou sacharidy a bílkoviny, právě sacharidy jsou hlavním zdrojem celkové energie piva. $V$ této souvislosti se pivo stalo základní součástí jídelníčku v mnoha kulturách (Bamforth, 2004). Vyvážené nutriční složení, minimální obsah cizorodých látek a konečně malý obsah alkoholu řadí pivo $v$ př́padě splnění podmínky umírněné konzumace tohoto nápoje mezi zdraví prospěšné nápoje. $V$ zahraniční literatuře je umírněná neboli moderovaná konzumace alkoholu obecně označována jako „moderate consumption“. Caorrao et al. (2000) a nověji Poli et al. (2013) dokazují, že pravidelná konzumace alkoholu obecně v dávkách $20-30 \mathrm{~g} /$ den pro muže a $10-15 \mathrm{~g} / \mathrm{den}$ pro ženy preventivně působí proti řadě onemocnění, především kardiovaskulárním, chrání před rozvojem aterosklerózy, omezuje shlukování krevních destiček a pozitivně zasahuje do lipidového metabolismu, a to tím, že zvyšuje hladinu tzv. "hodného“ cholesterolu HDL a naopak snižuje hladinu LDL cholesterolu.

Na téma „Pivo a zdraví" byla sepsána řada vědeckých článků, existuje též řada odborných publikací (Bamforth, 2004; Emmerová et al., 2010; Preedy, 2009). Pivo obsahuje až dva tisíce různých látek, z nichž nejvíce jsou zastoupeny sacharidy, bílkoviny, dále minerály, rozpustná vláknina, vitamíny skupiny $B$, a také rada polyfenolických sloučenin, kterým jsou přisuzovány antioxidační, antikarcinogenní a antimikrobiální účinky (Gordon, 1996).

Téma „Pivo a zdravi“", které je v tomto článku rozpracováno, je zaměřeno především na piva česká, nebot VúPS se touto problematikou zabývá $v$ dlouhodobém výzkumu. Jak již bylo popsáno v roce 2004 (Čejka, 2004), česká piva obsahují vyšší koncentrace zdraví prospěšných polyfenolických látek (průměrně 160 mg/l) nežli piva
Keywords: beer, health, phytoestrogens, vitamins $B$, biogenic amines, $\mathrm{N}$-nitrosamines, ATNC, microbiology contamination

\section{INTRODUCTION}

Beer is an important source of main nutrient substances such as carbohydrates and proteins; carbohydrates are the main source of the total energy of beer. Consequently, beer has become a fundamental part of the diet in many cultures (Bamforth, 2004). Balanced nutritional composition, the minimum content of contaminants, and low alcohol content make beer, on condition of moderate consumption, one of healthy drinks. In foreign literature, alcohol consumption, if not excessive, is generally referred to as a "moderate consumption". Caorrao et al. (2000) and more recently Poli et al. (2013) demonstrated that regular consumption of alcohol in doses of 20-30 g/day for men and 10-15 g/day for women has a preventive effect against various diseases, especially cardiovascular ones, protects against the development of atherosclerosis, reduces platelet aggregation, and positively affects lipid metabolism, increasing the levels of "good" HDL cholesterol and decreasing LDL cholesterol.

Numerous scientific articles and publications were written on the topic of "Beer and Health", (Bamforth, 2004; Emmerová et al., 2010; Preed, 2009). Beer contains up to two thousand different substances, most of which are represented by carbohydrates, proteins, minerals, soluble fiber, B vitamins, and a number of polyphenolic compounds, which are known to exert antioxidant, anticarcinogenic and antimicrobial effects (Gordon, 1996).

The theme of "Beer and Health", which is elaborated in this article, is primarily focused on Czech beer, as RIBM deals with this issue in a long-term research. As already described in 2004 (Čejka, 2004), Czech beers contain a higher concentration of healthy polyphenols (on average $160 \mathrm{mg} / \mathrm{l}$ ) than foreign beers. In recent years, 

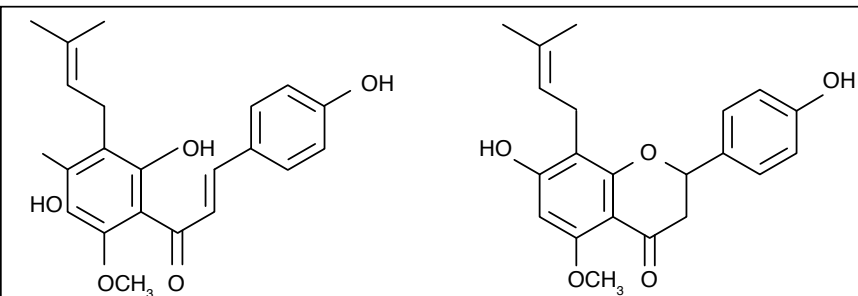

Xanthohumol (XN)

Isoxanthohumol (IX)

Obr. 1 Chemická struktura xanthohumolu a isoxanthohumolu / Fig. 1 Chemical structure of xanthohumol and isoxanthohumol

zahraniční. V posledních letech se výzkum zaměřil podrobněji právě na tyto mikronutrienty, zejména na tzv. flavonoidy, zahrnující některé významné fytohormony, a dále na vitamíny.

Flavonoidy jsou zdravotně významné látky, z nichž některé patří mezi tzv. fytoestrogeny, které přecházejí do piva z chmele i sladu. Jsou to prírodní antioxidanty s protinádorovými a antimikrobiálními účinky. V posledních letech je význam těchto látek stále více diskutován. Xanthohumol (obr. 1) působí jako inhibitor různých typů rakovinových nádorů a má antimikrobiální, protizánětlivé a antioxidační účinky. Ačkoli je xanthohumol dominantní prenylflavonoid ve chmelu, jeho koncentrace $v$ pivu je podstatně nižší, což je způsobeno termickou izomerizací na isoxanthohumol (obr. 1) (Stevens et al., 1999); tato látka pak vykazuje nižší bioaktivní účinky (Kondo, 2003). 8-prenylnaringenin (8-PN) (obr. 2) patří v současnosti mezi fytoestrogeny s nejsilnější bioaktivitou (Milligan et al., 1999). Isoflavonoidy daidzein, genistein (obr. 3) a jejich prekurzory formononetin a biochanin $\mathrm{A}$ jsou další a dlouho známé fytoestrogeny přítomné ve chmelu a sladu (Mikyška et al., 2007). Tyto látky inhibují růst a proliferaci určitých typů nádorů, dále mají antimikrobiální, antioxidační účinky a vykazují silný efekt proti osteoporóze (Adlercreutz et al., 1995; Foti et al., 2005; Medjakovic et al., 2000).

Vitamíny. Při monitoringu vitamínů v pivu jsme se zaměřili především na vitamíny, které mají stabilní chemickou strukturu a jsou rozpustné ve vodě, tedy na vitamíny skupiny $B$. Ty se v lidském organismu účastní látkové přeměny sacharidů, bílkovin, tuků, cholesterolu a nukleových kyselin, jsou nezastupitelné při procesu tvorby energie (formou koenzymů), dále jsou nezbytné při tvorbě a vývoji červených krvinek, ovlivňují stav lidské pokožky, vlasů a nehtů, jsou zásadní pro správnou činnost nervového a imunitního systému, podporují spánek, ovlivňují pamět a koncentraci. Vitamíny skupiny $B$ v pivu pocházejí ze sladu a částečně z kvasinek během fermentace - kvasného procesu.

Jestliže mluvíme na téma „Pivo a zdravi“, je nutné zmínit také možnost obsahu látek cizorodých. Legislativně je pivo považováno za „bezpečnou potravinu“, protože technologie výroby piva je vnímána jako dekontaminační proces. Ve většině prípadů tak tomu skutečně je. Z naší zkušenosti můžeme konstatovat, že velké a střední pivovary si pravidelně (minimálně jednou ročně) kontrolují nezávadnost svých výrobků. V rámci těchto rozsáhlých analýz (podle požadavků bývalého potravinového zákona a doporučení ČSPS) zaměřených na potenciální rizikové kontaminanty jsou sledovány koncentrace mykotoxinů, N-nitrosaminů, biogenních aminů, těžkých kovů, alifatických chlorovaných uhlovodíků, polychlorovaných bifenylů, aromatických uhlovodíků dusičnanů a v neposlední řadě je posuzována mikrobiologická čistota.

Z chemické povahy kontaminantů Ize většinou odvodit, jaký činitel způsobil jeho př́tomnost; zda se jedná o selhání některého z kroků technologie, nekvalitní suroviny nebo nedostatečnou hygienu v provozu. $V$ našem dvouletém monitoringu jsme se zaměřili především na biogenní aminy a N-nitrosaminy, které svou prítomností mohou signalizovat proběhlou mikrobiální kontaminaci. Při kontaminaci surovin, meziproduktů a hotového piva pak nehrozí jen poškození kvality hotového piva, ale i potenciální poškození zdraví spotřebitele.

Biogenní aminy jsou přírodní, biologicky aktivní látky, důležité pro fyziologické funkce. Jsou běžně obsaženy v nízkých koncentracích v různých potravinách a nápojích. Vznikají dekarboxylací aminokyselin. Jejich přítomnost ve vysokých koncentracích je však toxická. Psychoaktivní aminy mají vliv na centrální nervový systém, vasoaktivní aminy ovlivňují vaskulární systém. Jejich toxicita je silně závislá na účinnosti detoxikace; např. ethanol významně snižuje aktivitu monoaminoxidasy, což vede $\mathrm{k}$ inhibici odbourávání biogenních aminů z organizmu, a tím ke zvýšení jejich toxicity. Konzumace nápojů a potravin obsahujících zvýšenou koncentraci biogenních aminů může u citlivých osob vést k bolestem hlavy, zvracení, hypertenzi, těžkým alergickým záchvatům provázeným dušností, vyrážkou,

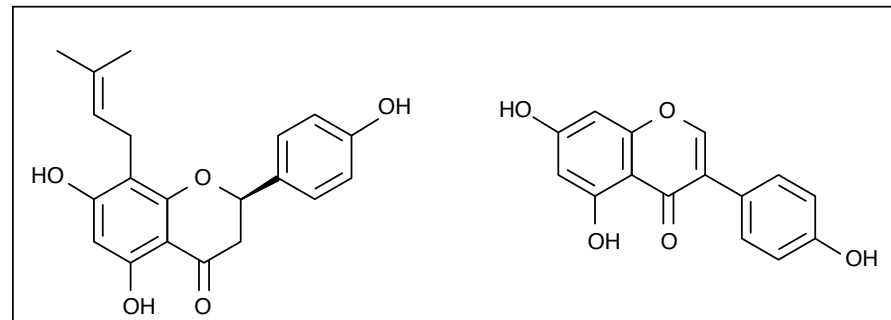

Obr. 2 Chemická struktura 8-prenylnaringeninu (vlevo) a genisteinu (vpravo) / Fig. 2 Chemical structure of 8-prenylnaringenin (left) and genistein (right)

research has focused in more detail on these micronutrients, particularly the flavonoids including some important plant hormones and vitamins.

Flavonoids are medically important substances, some of which belong to the so-called phytoestrogens, which get into beer from hops and malt. They are natural antioxidants with anticancer and antimicrobial effects. In recent years, the importance of these substances is increasingly debated. Xanthohumol (Fig. 1) acts as an inhibitor of various types of malignant tumors and has antimicrobial, anti-inflammatory and antioxidant effects. Although xanthohumol is the dominant prenylflavonoid in hops, its concentration in beer is considerably lower due to thermal isomerisation to isoxanthohumol (Fig. 1) (Stevens et al., 1999); the substance then exhibits a lower bioactive effects (Kondo, 2003). 8-Prenylnaringenin (8-PN) (Fig. 2) is currently among the phytoestrogens with the strongest bioactivity (Milligan et al., 1999). The isoflavones daidzein, genistein (Fig. 3) and their precursors formononetin and biochanin $A$ are long-known phytoestrogens present in hops and malt (Mikyška et al., 2007). These substances inhibit the growth and proliferation of certain tumors and exhibit antimicrobial and antioxidant effects and exert strong effect against osteoporosis (Adlercreutz et al., 1995; Foti et al., 2005; Medjakovic et al., 2000)

Vitamins. When monitoring vitamins in beer, we focused on vitamins that have a stable chemical structure and are water soluble, i.e. vitamins of the $B$ group. They participate in the metabolism of carbohydrates, proteins, fats, cholesterol, and nucleic acids, and are indispensable in the process of energy production (in the form of coenzymes). They are also essential in the formation and development of red blood cells, influence the state of human skin, hair and nails and are essential for the proper functioning of the nervous and immune system, promote sleep, and affect memory and concentration. B group vitamins in beer originate from malt and partly from yeast during fermentation.

When talking about "Beer and Health", we should also mention the possibility of foreign matter content. Beer is legislatively considered as "safe food" because the beer production technology is seen as a decontamination process. In most cases this is indeed the case. From our experience we can say that large and medium-sized breweries inspect the safety of their products on a regular basis (at least annually). Within the frames of these extensive analyzes (in the spirit of food laws and recommendations of the former Czech Union of Breweries and Malthouses) of potential risk contaminants are monitored concentrations of mycotoxins, N-nitrosamines, biogenic amines, heavy metals, chlorinated aliphatic hydrocarbons, polychlorinated biphenyls, aromatic hydrocarbons, nitrates and, last but not least, the microbiological purity is assessed.

The chemical nature of the contaminants can usually point to the factor that caused their presence: the failure of one of the technological steps, poor materials or inadequate hygiene in operation. In our two years of monitoring, we focused on biogenic amines and $\mathrm{N}$-nitrosamines whose presence may indicate microbial contamination. Contamination of raw materials, intermediates and finished beer may cause not only damage to the quality of the finished beer, but also potential harm to consumers.

Biogenic amines are natural biologically active substances, essential for the physiological functions of the body. They are commonly found in low concentrations in various foods and beverages and are formed by decarboxylation of amino acids. Their presence in high concentrations is toxic. Psychoactive amines have an effect on the central nervous system, vasoactive amines affect the vascular system. Their toxicity is strongly dependent on the efficiency of detoxification; e.g. ethanol significantly reduces the activity of 


Histamin

Obr. 3 Chemické struktury analyzovaných biogenních aminů / Fig. 3 Chemical structures of biogenic amines under study

a v extrémním prípadě i šoku a ztrátě vědomí. Účinky některých biogenních aminů mohou být synergické, současně byla prokázána jejich synergie $s$ alkoholem (to znamená, že mohou být jednotlivě $v$ malých tolerovaných množstvích, ale vzájemně se jejich účinky společně s reakcí s alkoholem násobí). Současná platná legislativa (Zákon č. 110 / $1997 \mathrm{Sb}$ ) povoluje maximální koncentraci histaminu v pivu $20 \mathrm{mg} / \mathrm{kg}$ (speciálně pro pivo) a tyraminu obecně v potravinách $100 \mathrm{mg} / \mathrm{kg}$ (obecně pro potraviny). Literatura (Anli et al., 2004) uvádí, že při konzumaci 8-40 mg histidinu dochází ke slabé otravě, při 40-100 mg k otravě střední a nad 100 mg k otravě silné. Při požití tyraminu v koncentraci vyšší než 100 mg může dojít $\mathrm{k}$ silné migréně. Chemické struktury biogenních aminů jsou uvedeny na obr. 3.

Biogenní aminy vyskytující se v pivu Ize rozdělit do dvou skupin. První skupina zahrnuje aminy, které primárně pocházejí ze sladu a dalších surovin a Ize je tak považovat za běžnou složku piva (putrescin, agmatin, spermin a spermidin). Do druhé skupiny můžeme zařadit histamin, tyramin a kadaverin, jejichž prítomnost v hotovém pivu zpravidla ukazuje na aktivitu kontaminujících bakterií během výroby piva (Kalač a Kř́žek, 2003). Významnými producenty biogenních aminů jsou mléčné bakterie a bakterie čeledi Enterobacteriaceae. Mléčné bakterie (Lactobacillus, Pediococcus) jsou zodpovědné především za produkci tyraminu a histaminu, zatímco např. Enterobacter nebo E. coli produkují především kadaverin a putrescin (Izquierdo-Pulido et al., 1996; Kalač a Křížek, 2003; Lorencová et al., 2012).

$\mathrm{N}$-nitrosaminy, které jsou nejvíce sledovány, jsou tzv. těkavé nitrosaminy (nejčastěji N-nitrosodimethylamin; NDMA) nebo celkové netěkavé ATNC (apparent total nitrosamine content). N-nitrosaminy přítomné v pivu pocházejí především ze sladu, kde vznikají při reakci sladových aminů s oxidy dusíku ze sušícího vzduchu. Ty se však většinou během technologického procesu vyředí, navíc je jejich koncentrace hlídána ve vstupním sladu.

Netěkavé $\mathrm{N}$-nitrosaminy mohou vznikat během pivovarského procesu, např. při přerušení varního procesu na dobu delší než 4 hodiny. $\mathrm{V}$ takovém případě může dojít $\mathrm{k}$ jejich tvorbě rozvojem bakterií $s$ nitrátreduktázovou aktivitou (tzn. redukují dusičnany na dusitany).

Významným producentem N-nitrosaminů je rod Bacillus (v průběhu rmutování) a bakterie čeledi Enterobacteriaceae (na začátku hlavního kvašení). N-nitrosaminy mají při dlouhodobé konzumaci hepatotoxické a karcinogenní účinky (postupné hromadění ve tkáních, vznik nádorů). Požadavky ČSPS udávají nejvyšší príípustné množství NDMA v pivu $0,5 \mu \mathrm{g} / \mathrm{kg}$. Na ATNC (celkové nitrososloučeniny) žádná norma $\checkmark$ EU neexistuje. Většinou je požadován obsah ATNC menší než 40 $\mu \mathrm{g} \mathrm{N}-\mathrm{NO} / \mathrm{kg}$, nebo $20 \mu \mathrm{g} \mathrm{N}-\mathrm{NO} / \mathrm{kg}$. Podíl těkavých nitrosaminů na celkovém obsahu ATNC činí jen cca $10 \%$. Kvalitní piva mají obsah zpravidla ATNC menší nebo roven $20 \mu \mathrm{g}$ N-NO/I. Zvýšený obsah ATNC je způsoben v převážné většině prípadů mikrobiální infekcí.

Cílem tohoto článku je sumarizovat výsledky monitoringu zdraví prospěšných látek $v$ českých pivech, ale zároveň upozornit na potenciální nebezpečí, kdy se $v$ pivu mohou vyskytnout látky opačného charakteru (biogenní aminy, N-nitrosaminy), a navrhnout, jak je eliminovat na minimum.

\section{MATERIÁL A METODY}

\subsection{Schéma experimentu}

Pro srovnání obsahu vybraných vitamínů $\mathrm{B}$ a flavonoidů $v$ komerčních pivech bylo zajištěno 22 vzorků tuzemských a 16 vzorků zahraničních piv (v roce 2012) a 22 vzorků tuzemských a 17 vzorků zahraničních piv typu světlý ležák (v roce 2013).

Pro monitoring obsahu biogenních aminů a ATNC (apparent total nitrosamine content) v letech 2011 a 2012 bylo zajištěno 67 vzorků $z$ velkých a středních pivovarů a 53 vzorků $z$ minipivovarů.

\subsection{Použitá metoda}

Metoda stanovení vitamínu B v pivu byla převzata z literatury (Albala-Hurtado et al., 1997; Dong et al., 1998; ĆSN EN 14122) a optimalizována pro danou matrici. Tato metoda je interní metodikou VÚPS. Vzorek piva byl analyzován na kapalinovém chromatografu Ultimate 3000 (Dionex), na chromatografické koloně Nucleosil C18 (250 x 4 mm ID, $5 \mu \mathrm{m}$, monoamine oxidase, which leads to inhibition of the degradation of biogenic amines from the body, thereby increasing their toxicity. Consumption of beer, other drinks or food containing elevated concentrations of biogenic amines may lead to headache, vomiting, hypertension, severe allergic attacks accompanied by shortness of breath, rash, and in extreme cases shock and loss of consciousness. The effects of certain biogenic amines can be synergistic and their synergy with alcohol was proven (i.e., in small amounts they can be individually tolerated, but their effects, when combined with the reaction to alcohol, are multiplied). Current legislation allows a maximum concentration of histamine in the beer $20 \mathrm{mg} / \mathrm{kg}$ (especially beer) and tyramine in foods generally $100 \mathrm{mg} / \mathrm{kg}$ (generally for food). The literature (Anli et al., 2004) states that the consumption of 8-40 mg of histidine leads to weak poisoning, at $40-100 \mathrm{mg}$ a medium poisoning appears and strong poisoning appears on ingesting more than $100 \mathrm{mg}$. Ingestion of tyramine at a concentration greater than $100 \mathrm{mg}$ may cause severe migraine. Chemical structures of biogenic amines are shown in Fig. 3.

Biogenic amines occurring in beer can be divided into two groups. The first group includes amines that come primarily from malt and other raw materials and can thus be considered as normal components of beer (putrescine, agmatine, spermine and spermidine). The second group includes histamine, tyramine and cadaverine whose presence in the finished beer usually points to the activity of contaminating bacteria in beer production (Kalač and Kř́žek, 2003). Major producers of biogenic amines are lactic acid bacteria and Enterobacteriaceae. Lactic bacteria (Lactobacillus, Pediococcus) are responsible mainly for the production of tyramine and histamine whereas Enterobacter or E. coli primarily produce cadaverine and putrescine (Izquierdo-Pulido et al., 1996; Kalač and Křižek, 2003; Lorencová et al., 2012).

$\mathrm{N}$-nitrosamines, which are the most intensively monitored, include the so-called volatile nitrosamines (mostly N-nitrosodimethylamine, NDMA) or the total nonvolatile ATNC. N-nitrosamines present in the beer come mainly from the malt and are formed by the reaction of malt amines with nitrogen oxides from the drying air. They are, however, usually strongly diluted during subsequent processing and their concentration in the monitored input malt is closely surveyed.

Non-volatile $\mathrm{N}$-nitrosamines may be formed during the brewing process, e.g. when the brewing is interrupted for more than four hours. In this case, they may be formed due to the nitrate reductase activity of proliferating bacteria, which reduce nitrate to nitrite.

An important producers of $\mathrm{N}$-nitrosamines is the genera Bacillus (during mashing) and Enterobacteriaceae (beginning of the main fermentation). Long-term consumption of $\mathrm{N}$-nitrosamines has hepatotoxic and carcinogenic effects (progressive accumulation in the tissues, formation of tumors). The requirements of the Czech Union of Breweries and Malthouses (CSPS) state as the maximum permissible amount of NDMA in beer $0.5 \mathrm{mg} / \mathrm{kg}$. No standard EU exists for the ATNC (total nitroso compounds). The required content of ATNC is usually less than 40 micrograms $\mathrm{N}-\mathrm{NO} / \mathrm{kg}$, or 20 micrograms $\mathrm{N}-\mathrm{NO} / \mathrm{kg}$. The proportion of volatile nitrosamines in the total content ATNC is only about $10 \%$. The ATNC content in quality beers is usually less than or equal to 20 $\mathrm{mg} \mathrm{N}-\mathrm{NO} / \mathrm{l}$. Increased content ATNC is caused in most cases by microbial infections.

The aim of this article is to summarize the results of the monitoring of health-promoting substances in Czech beers, but also highlight the potential dangers of health-deleterious substances (biogenic amines, N-nitrosamines) that may occur in beer, and suggest ways of minimizing them.

\section{MATERIALS AND METHODS}

\subsection{Scheme of the experiment}

The comparison of selected $B$ vitamins and flavonoids in commercial beers was performed on 22 samples of domestic and 16 samples of imported beers in 2012 and 22 samples of domestic and 17 samples of foreign lager-type beers in 2013. 

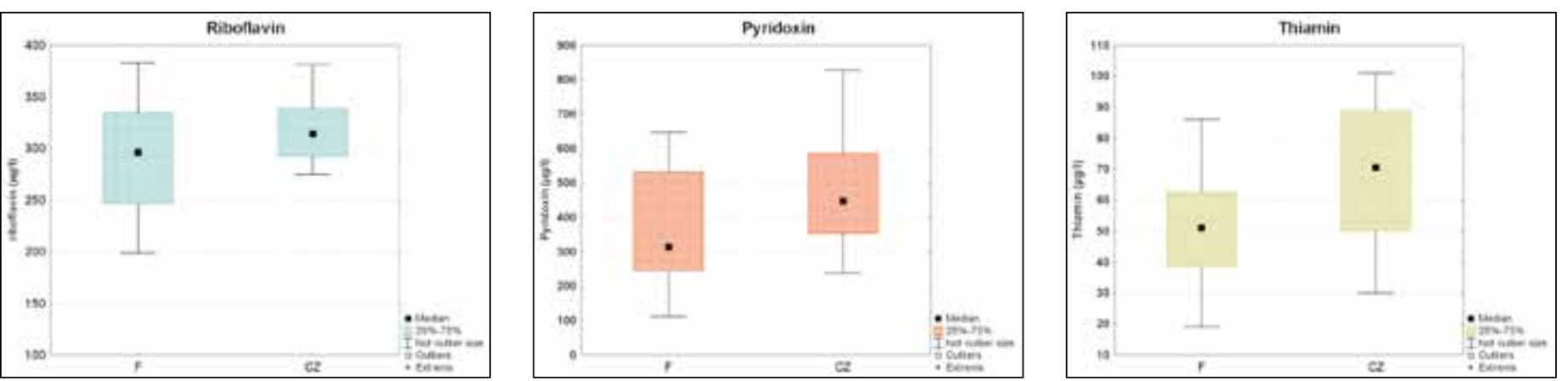

Obr. 4 Porovnání obsahů vitamínů $\mathrm{B}$, thiaminu, riboflavinu a pyridoxinu v českých a zahraničních pivech (vlevo zahraniční piva, vpravo česká piva) / Fig. 4 Comparison of the content of vitamins B - thiamine, riboflavin and pyridoxine - in Czech and foreign beers (left - foreign beers, right - Czech beers)

Tab. 1 Průměrný obsah vitamínů B v 0,5 I českého ležáku / Table 1 Average content of vitamins $B$ in 0.5 liters Czech lager

\begin{tabular}{|l|c|c|}
\hline Vitamin & $\boldsymbol{\mu g} / \mathbf{0 , 5} \mathbf{~}$ & \% RDI \\
\hline Thiamin / Thiamine (B1) & $35^{\star \star}$ & 2.4 \\
\hline Riboflavin (B2) & $125^{\star \star}$ & 7.4 \\
\hline Niacin (B3) & $2500^{\star}$ & 12.5 \\
\hline Panthotenová kys. / Panthotenate (B5) & $600^{\star}$ & 6.0 \\
\hline Pyridoxin / Pyridoxine (B6) & $250^{\star \star}$ & 12.5 \\
\hline Folová kyselina / Folic acid (B9) & $100^{\star}$ & 25.0 \\
\hline Kobalamin / Cobalamin (B12) & $1^{*}$ & 16.0 \\
\hline
\end{tabular}

*Basařová et al., Pivovarství, teorie a praxe výroby piva, VŠCHT Praha, 2010 / Basařová et al., Brewing, theory and practice of brewing, ICTP, 2010

**výsledky VÜPS / RIBM results

$\mathrm{RDI}$ - Recommended Daily Intake = doporučená denní dávka / RDI - Recommended Daily Intake = recommended daily dose

Macherey-Nagel) chráněné předkolonou C18. Mobilní fáze byla tvořena $5 \mathrm{mM}$ hexansulfonátem sodným, $1 \%$ octovou kyselinou s prídavkem $0,13 \%$ triethylamin-acetonitril $(85: 15 \mathrm{v} / \mathrm{v})$. Analýza probíhala $\mathrm{v}$ izokratickém módu při průtoku $1 \mathrm{ml} / \mathrm{min}$ a teplotě kolony $30^{\circ} \mathrm{C}$. $\mathrm{K}$ detekci byl použit fluorimetrický detektor za podmínek pro jednotlivé vitamíny: B1 excitace 364, emise $434 \mathrm{~nm}$; B2 excitace 440, emise $520 \mathrm{~nm}$; B6 excitace 288 , emise $418 \mathrm{~nm}$. Thiamin byl před analýzou derivatizován $0,5 \mathrm{ml}$ zfiltrovaného extraktu nebo piva se smíchá s $0,5 \mathrm{ml}$ derivatizačního činidla (směs $10 \mathrm{ml} 1 \%$ roztoku ferrikyanidu draselného a $30 \mathrm{ml} \mathrm{15 \%}$ $\mathrm{NaOH}$ ) a po důkladném promíchání se inned analyzuje.

Flavonoidy byly stanoveny metodou HPLC s UV detekcí podle nově vyvinuté metody Jurková et al. (2013).

Biogenní aminy byly stanoveny metodou HPLC s fluorescenční detekcí podle interní metodiky VúPS. Pivo se odpění za pomocí ultrazvukové lázně a zředí fosfátovým pufrem pro prípravu vzorku $v$ poměru 1:1 a dále se extrahuje na SPE kolonkách Discovery DSC-MCAX. Po kondicionaci kolonky a její ekvilibraci je vzorek nanesen na kolonku, promýván fosfátovým pufrem $(\mathrm{pH}=3)$. Eluce basických aminů se provede $1 \% \mathrm{NaOH} v$ methanolu a přidá se interní standard (1,7-diaminoheptan $v$ methanolu). Poté je vzorek derivatizován orthoftalaldehydem rozpuštěným ve směsi methanolu a borátového pufru. Takto pripravený vzorek je analyzován na HPLC s fluorescenčním detektorem na chromatografické koloně Luna C18

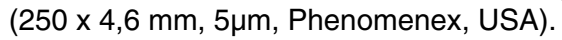

Hodnoty ATNC byly stanoveny podle literatury (Walters et al., 1983). Metodou je stanoven celkový obsah skupiny N-NO ve vzorku. Pomocí roztoku bromovodíku v octové kyselině je odštěpen oxid dusnatý a nitrosylbromid. Tyto sloučeniny jsou pomocí katalytického štěpení převedeny na nitrosylový radikál. Nitrosylový radikál následně reaguje s ozonem za vzniku excitovaného oxidu dusičitého a ten je detekován chemiluminiscenčním detektorem TEA.

\section{VÝSLEDKY A DISKUSE}

\subsection{Látky se zdravotním účinkem}

Jak vyplývá ze získaných výsledků, česká piva obsahují průměrně o $30 \%$ více vitamínu B1 (thiaminu, $70 \mu \mathrm{g} / \mathrm{l}$ ), o $20 \%$ více vitamínu B2 (riboflavinu, $320 \mu \mathrm{g} / \mathrm{l}$ ), o $45 \%$ více vitamínu B6 (pyridoxinu, $450 \mu \mathrm{g} / \mathrm{l}$ ) než piva zahraniční. Tato data jsou přehledně znázorněna formou krabicových grafů na obr. 4 .
The monitoring of the content of biogenic amines and ATNC (apparent total nitrosamine content) between 2011 and 2012 was performed on 67 samples from large and medium-sized breweries and 53 samples from microbreweries.

\subsection{The methodology}

The method for determination of vitamin $B$ in beer was taken from the literature (AlbalaHurtado et al., 1997; Dong et al., 1998; DIN EN 14122) and optimized for a given matrix. This method is an internal methodology of the RIBM. Beer samples were analyzed on Ultimate 3000 (Dionex) liquid chromatograph, column chromatography was performed on a Nucleosil C18 column $(250 \mathrm{x}$ $4 \mathrm{~mm}$ ID, $5 \mathrm{~mm}$, Macherey-Nagel) protected by a $\mathrm{C} 18$ precolumn. The mobile phase consisted of $5 \mathrm{mM}$ sodium hexanesulfonate and $1 \%$ acetic acid with addition of $0.13 \%$ triethylamine-acetonitrile $(85: 15 \mathrm{v} / \mathrm{v})$. Analysis was carried out in the isocratic mode at a flow rate of $1 \mathrm{ml} / \mathrm{min}$ and a column temperature of $30{ }^{\circ} \mathrm{C}$. Fluorometric detection was done under conditions suitable for the individual vitamins: B1 - excitation $364 \mathrm{~nm}$, emission $434 \mathrm{~nm}$; B2 - excitation $440 \mathrm{~nm}$, emission $520 \mathrm{~nm}$; B6 - excitation $288 \mathrm{~nm}$, emission $418 \mathrm{~nm}$. Thiamine was derivatized before analysis. The volume of $0.5 \mathrm{ml}$ of the filtered extract or beer was mixed with $0.5 \mathrm{ml}$ of derivatization reagent (a mixture of $10 \mathrm{ml} 1 \%$ solution of potassium ferricyanide and $30 \mathrm{ml}$ of $15 \% \mathrm{NaOH}$ ), thoroughly mixed and immediately analyzed.

Flavonoids were determined by HPLC with UV detection by a newly developed method of Jurková et al. (2013).

Biogenic amines were determined by HPLC with fluorescence detection according to internal RIBM methodology. Beer was defoamed using an ultrasound bath, diluted with phosphate buffer to prepare a sample in a 1:1 ratio, and further extracted on Discovery DSC- MCAX SPE columns. After column equilibration the sample was applied to the column and washed with phosphate buffer $(\mathrm{pH}=3)$. Elution of basic amines was done by $1 \% \mathrm{NaOH}$ in methanol and an internal standard (1,7-diaminoheptane in methanol) was added. The sample was then derivatized by ortho-phthalaldehyde dissolved in methanol and borate buffer. The sample thus prepared was analyzed by HPLC with fluorescence detector on a chromatographic column Luna C18 $(250 \times 4.6 \mathrm{~mm}, 5 \mu \mathrm{m}$, Phenomenex, USA).

ATNC were determined according to the literature (Walters et al., 1983). The method determines the total content of N-NO groups in a sample. Carbon monoxide and nitrosyl were cleaved off with a solution of hydrogen bromide in acetic acid. These compounds were then converted to the nitrosyl radical via catalytic cleavage. Nitrosyl radical then reacted with ozone to form excited nitrogen oxide and was detected by the TEA chemiluminescent detector.

\section{RESULTS AND DISCUSSION}

\subsection{Substances with health-beneficial effect}

As follows from the results obtained in the study, Czech beer contains on average $30 \%$ more vitamin B1 (thiamine, $70 \mathrm{mg} / \mathrm{l}$ ), $20 \%$ 
Ze získaných dat a tab. 1 vyplývá, že pivo je významným zdrojem vitamínů $B$. Při konzumaci 2 piv denně (což splňuje požadavek moderovaného pití, jak uvádí Caorrao et al. 2000 a Poli et al., 2013) získá konzument $50 \%$ denní dávky folátů, $25 \%$ dávky niacinu a pyridoxinu.

Dále bylo $v$ rámci monitoringu zdraví prospěšných látek zjištěno, že česká piva obsahují asi o $50 \%$ více prenyflavonoidů (xanthohumol $16 \mu \mathrm{g} / \mathrm{l}$, isoxanthohumol $1000 \mu \mathrm{g} / \mathrm{l})$ a o $40-50 \%$ více fytohormonů, konkrétně 8-prenylnaringenin $(35 \mu \mathrm{g} / \mathrm{l})$ a genistein $(800 \mu \mathrm{g} / \mathrm{l})$ než piva zahraniční. Tyto výsledky jsou dokumentovány na obr. 5 a 6 .

\subsection{Cizorodé látky}

Získané hodnoty biogenních aminů byly v prvním kroku srovnány $s$ dalšími publikovanými daty. Na obrázku $7 A, 7 B$ a $7 C$ je uvedeno srovnání našich dat se světovou statistikou (Kalač a Kř́žžek, 2003).

$Z$ hlediska možných negativních dopadů na zdraví člověka je nejvýznamnějším biogenním aminem histamin (Shalaby, 1996). Kalač et al. (2003) uvádí max. nalezenou koncentraci histaminu 21,6 mg/l ve vzorku evropského piva (měřeno 195 piv), monitoring VúPS zahrnuje pouze piva česká (67 vzorků) s maximální nalezenou hodnotou 19,8 mg/l.

Maximální hodnoty tyraminu jsou podle výsledků VÚPS 80 mg/l (z 67 piv). Kalač a Křižek (2003) uvádějí maximální hodnotu 67,5 mg/l (statistika z 195 vzorků piv). Tyramin je, podobně jako histamin, biogenním aminem, který vzniká metabolickou činností kontaminujících mikroorganismů, zejména bakterií mléčného kvašení (Kalač a Kř́žek, 2003).

Obě studie se $v$ prípadě kadaverinu shodují v závěru, že česká piva obsahují vysoké koncentrace kadaverinu, VÚPS studie udává maximální hodnotu 59,7 mg/l (ze 67 vzorků piv) a studie autorů Kalač a Kř́žek (2003) uvádí hodnotu 49,1 mg/l (ze 78 vzorků českých piv). Kadaverin má sice slabší toxické účinky než histamin a tyrosin, ale zesiluje toxické účinky právě těchto dvou aminů.

Další srovnání bylo provedeno s výsledky autorů Buňka et al. (2012) provedených na UTB Zlín. Na obrázcích $8 A$ a $8 B$ je uvedeno relativní zastoupení tyraminu $(8 \mathrm{~A})$ a kadaverinu $(8 \mathrm{~B}) \vee$ českých světlých pivech vyrobených ve velkých a středních pivovarech. Oba monitoringy se shodují v prípadě tyraminu, v $75 \%$ př́padů byl tyramin prítomen v koncentračním rozmezí $0-10 \mathrm{mg} / \mathrm{l}$, asi $20 \%$ př́padů obsahovalo pivo $10-50 \mathrm{mg} / \mathrm{l}$ tyraminu a pouze $5 \%$ piv obsahovalo tyramin v koncentraci 50-100 mg/l. V prípadě kadaverinu se výsledky nepatrně liší, výsledky UTB (Buňka et al., 2012) vykazují vyšší četnost piv s vyššími koncentracemi kadaverinu.

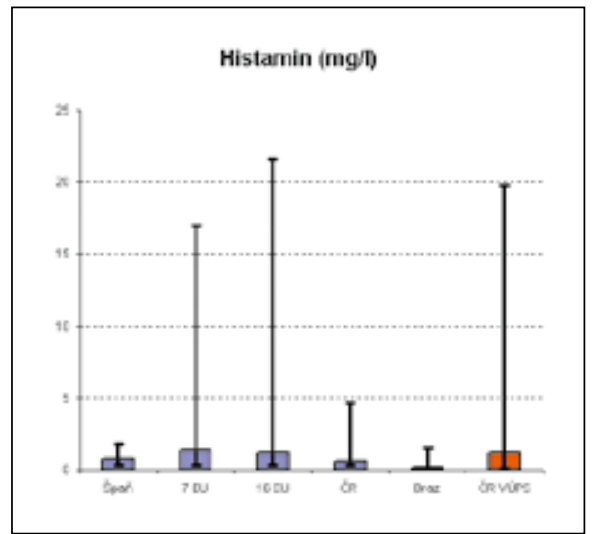

Obr.7A Srovnání koncentrací histaminu, výsledky monitoringu VÚPS a autorů (Kalač a Křížek, 2003) / Fig. 7A Comparison of total histamine concentrations obtained by RIBM monitoring with those of Kalač and Křížek (2003)

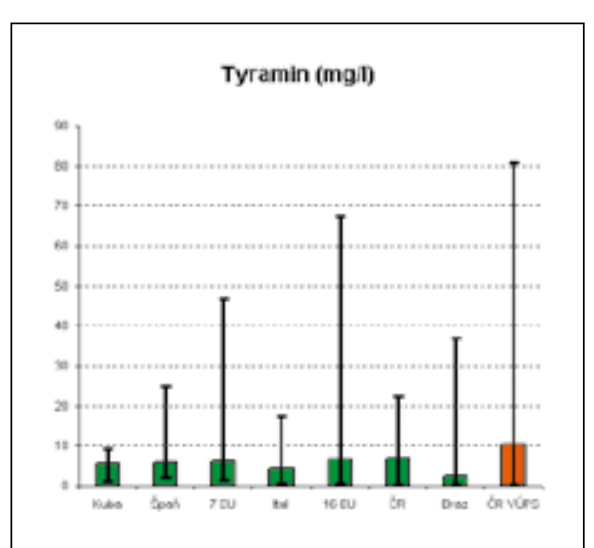

Obr. 7B Srovnání koncentrací tyraminu, výsledky monitoringu VÚPS a autorů (Kalač a Křížek, 2003) / Fig. 7B Comparison of total concentrations of tyramine obtained in RIBM monitoring with that reported by Kalač and Krížek (2003)

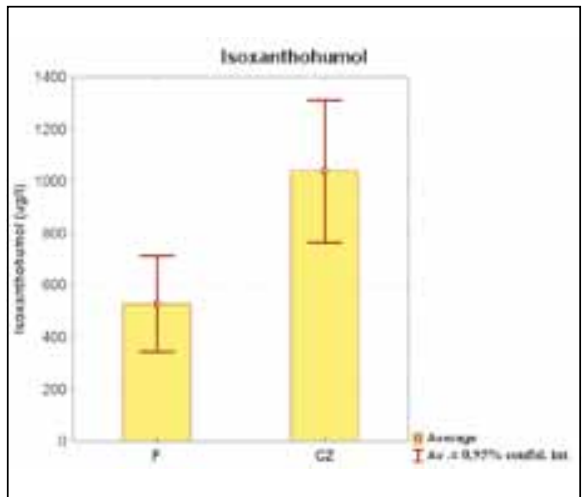

xanthohumol a isoxanthohumol) v českých a zahraničních pivech (vlevo zahraniční piva, vpravo česká piva) / Fig. 5 Comparison of the contents of prenylflavonoids (xanthohumol and isoxanthohumol) in Czech and foreign beers (left - foreign beers, right - Czech beers)

Obr. 6 Porovnání obsahů vybraných fytohormonů (8-prenylnaringenin a genistein) v českých a zahraničních pivech (vlevo zahraniční piva, vpravo česká piva) / Fig. 6 Comparison of the contents of selected phytohormones (8- prenylnaringenin and genistein) in Czech and fore-

more vitamin B2 (riboflavin, $320 \mathrm{mg} / \mathrm{l}$ ), 45\% more vitamin B6 (pyridoxine, $450 \mathrm{mg} / \mathrm{l}$ ) than foreign beers. These data are clearly shown in the form of box plots in Fig. 4

The data at Table 1 show that beer is a significant source of vita$\min \mathrm{B}$. When consuming 2 beers a day (which meets the requirement of moderated drinking as stated by Caorrao et al., 2000, and Poli et al., 2013) the consumer receives $50 \%$ of the daily dose of folate, $25 \%$ of the dose of niacin and pyridoxine.

The monitoring of health-beneficial substances also revealed that Czech beer contains about $50 \%$ more prenyflavonoids (xanthohumol $16 \mathrm{mg} / \mathrm{l}$, isoxanthohumol 1000 micrograms/l) and $40-50 \%$ more plant hormones, namely 8-prenylnaringenin $(35 \mathrm{mg} / \mathrm{l})$ and genistein $(800 \mathrm{mg} / \mathrm{l})$. These results are documented in Fig. 5 and 6.

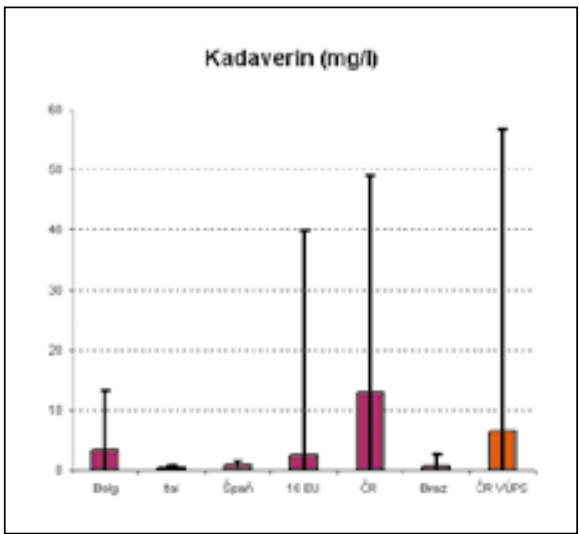

Obr. 7C Srovnání koncentrací kadaverinu, výsledky monitoringu VÚPS a autorů (Kalač a Křížek, 2003) / Fig. 7C Comparison of total concentrations of cadaverine obtained by RIBM monitoring with those reported by Kalač and Krížek (2003) 


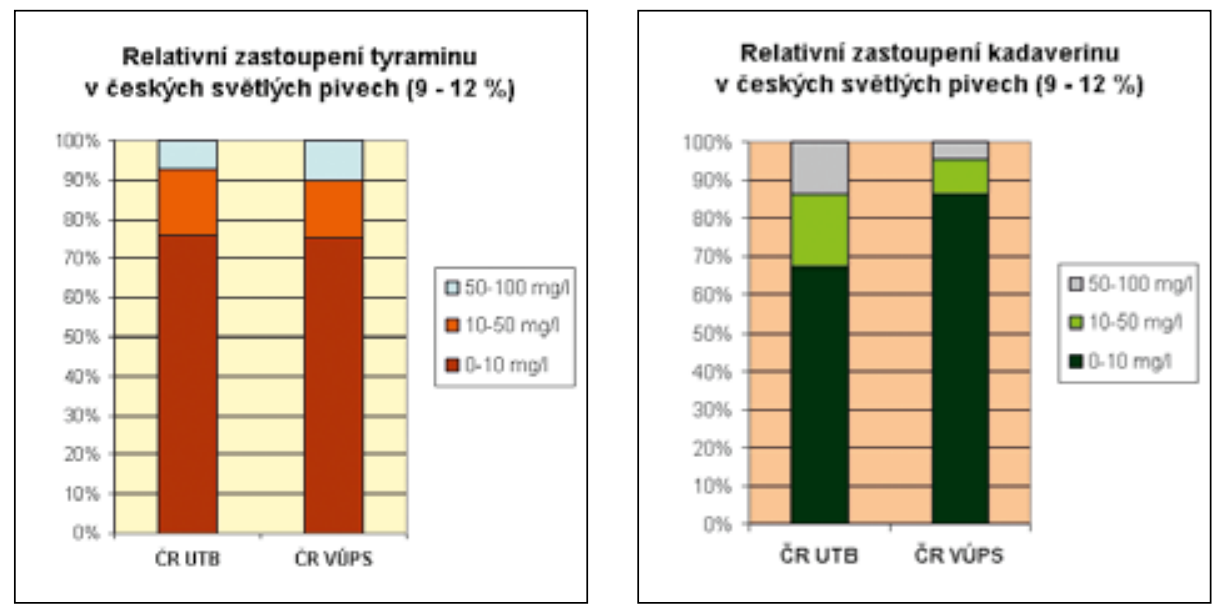

Obr. 8A (vlevo) a 8B (vpravo). Relativní zastoupení tyraminu a kadaverinu v českých světlých pivech vyrobených ve velkých a středních pivovarech / Fig. $8 A$ (left) and $8 B$ (right). The relative abundance of tyramine and cadaverine in Czech pale beers produced in large and medium-sized breweries

Jelikož bylo z výsledků na první pohled patrné, že koncentrace biogenních aminů a dále uvedených $\mathrm{N}$-nitrosaminů jsou zvýšené především ve vzorcích odebraných v českých minipivovarech, byly výsledky v tomto duchu dále vyhodnoceny. Na obr. 9 je znázorněn histogram obsahu tyraminu $v$ pivu ve dvou skupinách piv, první skupinu tvoři piva z velkých a středních pivovarů, druhou skupinu piv tvoří piva z minipivovarů. Jak z tohoto obrázku vyplývá, u první skupiny vzorků je zvýšena četnost piv s nízkým obsahem tyraminu (0-10 mg/l). U druhé skupiny vidíme vysokou četnost vzorků v celém rozmezí až do $100 \mathrm{mg} / \mathrm{l}$.

Tytéž výsledky, znázorněné jinou formou, demonstruje obr. 10. Čtverec vyjadřuje medián změřených hodnot, tímto bodem prochází rozptylová úsečka, z které můžeme vyčíst minimální a maximální hodnotu. Červené úsečky znázorňují výsledky z velkých a středních pivovarů, úsečky zelené znázorňují výsledky z minipivovarů. Z obrázku je zřejmé, že existují minipivovary, které mají obsah biogenních aminů v pivu vyšší než 100 mg/l.

Tab. 2 podrobně ukazuje získané hodnoty biogenních aminů a ATNC z 24 vzorků piva z minipivovarů (monitoring v roce 2011).

Podobné hodnoty byly získány v opakovaném monitoringu v roce 2012, data jsou zpracována ve formě korelace obsahu biogenních aminů a ATNC. Korelační diagram je uveden na obr. 11. Ze získané korelace (korelační koeficient je $r=0,74$ ) vyplývá, že přítomnost těchto dvou typů látek skutečně koreluje a lze tvrdit, že míra této korelace ukazuje na stupeň mikrobiální kontaminace testovaného piva. Získané výsledky jsou ukazatelem snížené hygienické kvality u některých minipivovarů v České republice. Zvýšený obsah histaminu a tyraminu $v$ hotovém pivu je poměrně spolehlivým indikátorem proběhlé kontaminace mléčnými bakteriemi, zejména pediokoky

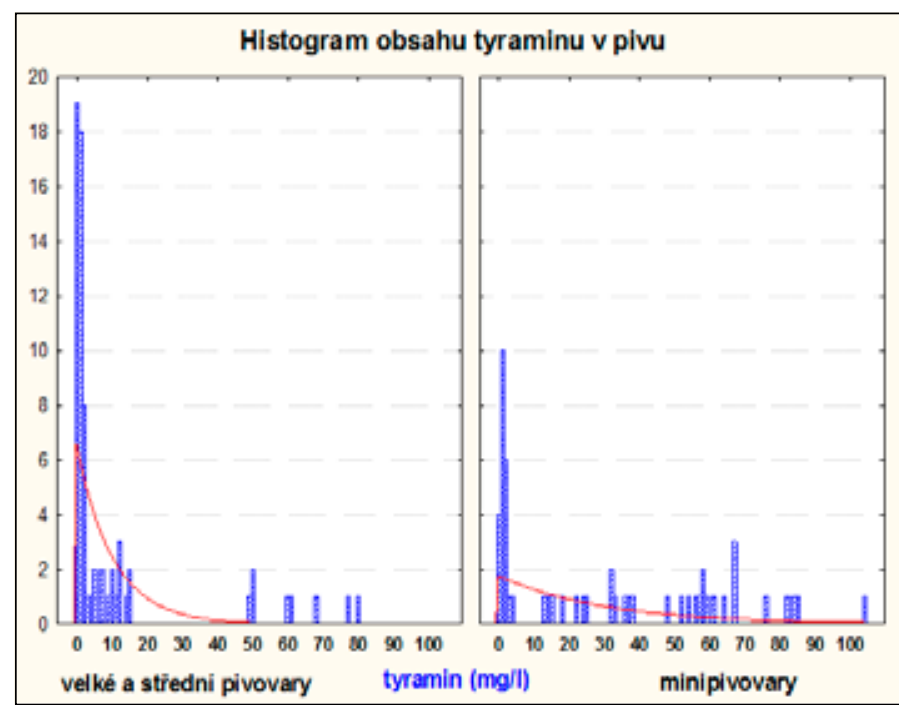

Obr. 9 Srovnání obsahu tyraminů v pivech z velkých a středních pivovarů a v pivech z minipivovarů / Fig. 9 Comparison of tyramine content in beers from large and medium-sized breweries and beers from microbreweries

\subsection{Foreign substances}

In the first step, the values of biogenic amines were compared with other published data. Fig. $7 A, 7 B$ and $7 C$ show a comparison of our data with global statistics (Kalač and Krížek, 2003)

The most important biogenic amine in terms of potential negative impacts on human health is histamine (Shalaby, 1996). Kalač and Křižek (2003) reported the maximum determined histamine concentration of $21.6 \mathrm{mg} / \mathrm{l}$ in a sample of European beers (195 beers analyzed); the RIBM monitoring includes only Czech beers (67 samples), with the maximum determined value $19.8 \mathrm{mg} / \mathrm{l}$.

Maximum tyramine values found in RIBM are $80 \mathrm{mg} / \mathrm{l}$ (from 67 beers). Kalač and Krížek (2003) reported the maximum value of $67.5 \mathrm{mg} / \mathrm{l}$ (a set of 195 beer samples). Like histamine, tyramine is a biogenic amine formed due to the metabolic activity of contaminating microorganisms, in particular lactic acid bacteria (Kalač and Kř́žzek, 2003).

In the case of cadaverine, both studies agree in the conclusion that the Czech beers contain high concentrations of cadaverine; RIBM study indicates a maximum value of $59.7 \mathrm{mg} / \mathrm{l}$ (67 samples of beers) while the study of Kalač and Křížek (2003) reports on $49.1 \mathrm{mg} / \mathrm{l}$ (78 samples of Czech beers). Cadaverine has weaker toxic effects than histamine and tyrosine, but potentiates the toxic effects in these two amines.

Another comparison was made with the results of the study by Buňka et al. (2012) conducted at Bata Technical University Zlín. Fig. $8 A$ and $8 B$ give the relative representation of tyramine $(8 \mathrm{~A})$ and cadaverine $(8 \mathrm{~B})$ in Czech pale beers produced in large and medium-sized breweries. Both monitorings are identical in the case of tyramine; in $75 \%$ of cases, tyramine was present in the concentration range $0-10 \mathrm{mg} / \mathrm{l}$, about $20 \%$ of the beers contained $10-50 \mathrm{mg} / \mathrm{l}$ tyramine and only $5 \%$ of beers contained tyramine at a concentration of $50-100 \mathrm{mg} / \mathrm{l}$. The results slightly differ in the case of cadaverine; the BTU results (Buňka et al., 2012) show higher frequencies of beers with higher concentrations of cadaverine.

As was immediately apparent from the results, the listed concentrations of biogenic amines and $\mathrm{N}$-nitrosamines are elevated above all in samples collected in Czech microbreweries. The data were therefore further analyzed in this sense. Fig. 9 shows a histogram of tyramine content in beers in two groups; one group consists of beers from large and medium-sized breweries, the other consists of beers from microbreweries. As shown in the figure, the former group of samples exhibits more beers with a low content of tyramine (0-10 $\mathrm{mg} / \mathrm{l})$ whereas the latter group shows a high frequency of samples with tyramine concentrations ranging up to $100 \mathrm{mg} / \mathrm{l}$.

The same results, presented in another form, are demonstrated in Fig. 10. The square indicates the median of the measured values; through this point passes the scatter bar, which shows the minimum and maximum value. The red lines show the results from large and medium-sized breweries, green lines show the results from microbreweries. The figure provides evidence that in some breweries the content of biogenic amines in beer may reach above $100 \mathrm{mg} / \mathrm{l}$.

Table 2 shows in detail the values of biogenic amines and ATNC in 24 samples of beer from microbreweries (monitored in 2011). The blue-highlighted data indicate microbial contamination of test beers, red-tinged data indicate beers that can be described as unsanitary.

Similar values were obtained in a repeated monitoring in 2012 . The data were processed in the form of correlations of the contents of biogenic amines and ATNC. The correlation diagram is shown in Fig. 11. The correlation (correlation coefficient $r=0.74$ ) indicates that the presence of these two types of substances actually correlates, and it can be argued that the degree of correlation indicates the degree of microbial contamination of the tested beer. The results are an indicator of reduced hygienic quality in some microbreweries in the Czech Republic. Increased content of histamine and tyramine in the finished beer is a fairly reliable indicator of contamination by lactic acid bacteria, particularly by pediococci (Izquierdo-Pulido et al., 1997). Increased content of cadaverine can 


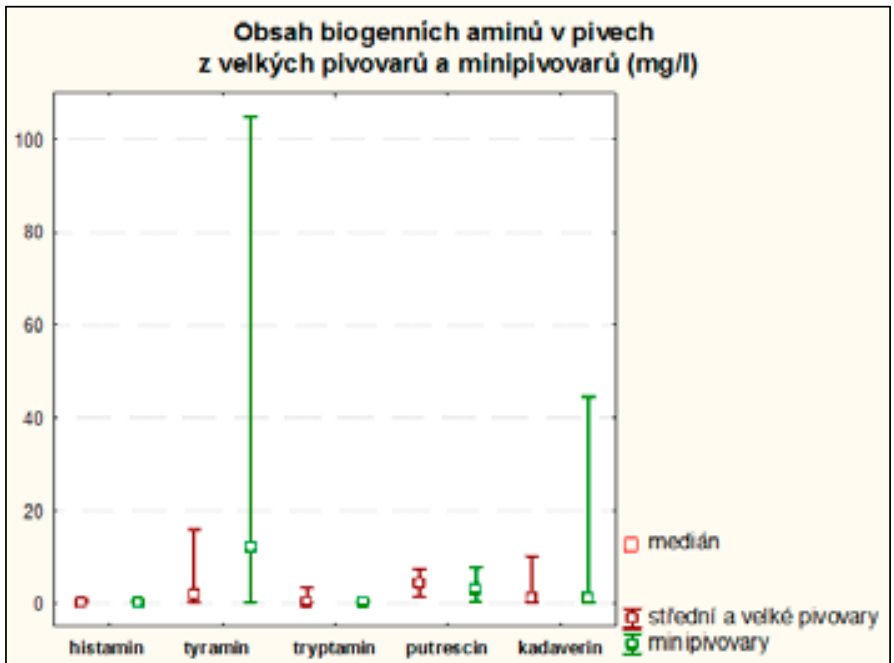

Obr. 10 Srovnání obsahu biogenních aminů v pivu z velkých a středních pivovarů (červeně) a minipivovarů (zeleně) / Fig. 10 Comparison of biogenic amines in beers from large and medium-sized breweries (red) and microbreweries (green)

(Izquierdo-Pulido et al., 1997). Zvýšený obsah kadaverinu Ize považovat za následek kontaminace kvasnic nebo mladiny enterobakteriemi (Kalač a Křížek, 2003).

$\mathrm{Na}$ závěr je nutno podotknout, že schopnost mikroorganismů produkovat biogenní aminy je kmenově specifická a může být ovlivněna různými faktory. Znamená to, že ne každý kmen schopný množit se $\checkmark$ pivu nebo jeho meziproduktech je producentem biogenních aminů (Greif et al., 1998; Kalač a Kř́ížek, 2003).

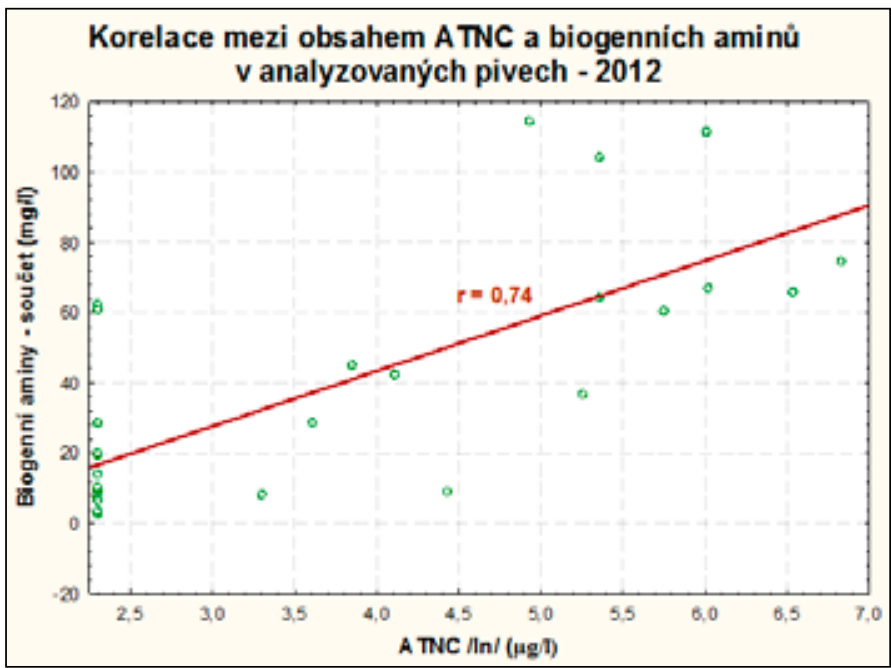

Obr. 11 Korelace sumy biogenních aminů a ATNC $v$ analyzovaných pivech / Fig. 11 Correlation of the sum of biogenic amines and ATNC in anlyzed beers

be seen to reflect the contamination of yeast or wort by enterobacteria (Kalač and Křížek, 2003).

Finally, it should be noted that the ability of microorganisms to produce biogenic amines is strain specific and can be affected by various factors. This means that not every strain able to multiply in beer or its intermediates produces biogenic amines (Greif et al., 1998; Kalač and Křížek, 2003).

Tab. 2 Obsah biogenních aminů a ATNC v pivech z minipivovarů (monitoring 2011). Modře jsou označeny výsledky, které ukazují na mikrobiální kontaminaci testovaného piva, výsledky podbarvené červeně označují piva, která lze označit za zdravotně závadná / Table 2 The values of biogenic amines and ATNC in beers from microbreweries (monitored in 2011). The blue-highlighted data indicate microbial contamination of test beers, red-tinged data indicate beers that can be described as unsanitary

\begin{tabular}{|c|c|c|c|c|c|c|c|c|c|}
\hline $\begin{array}{l}\text { Vzorek / } \\
\text { Sample }\end{array}$ & $\begin{array}{c}\text { Extrakt } \\
\text { mladiny (\% } \\
\text { hm.) / Wort } \\
\text { extract } \\
\text { (\% wt.) }\end{array}$ & $\begin{array}{c}\text { Alkohol } \\
\text { (\% obj.) I } \\
\text { Alcohol } \\
\text { (\% vol.) }\end{array}$ & $\begin{array}{c}\text { ATNC } \\
(\mu \mathrm{g} / \mathrm{l} \mathrm{N}-\mathrm{NO})\end{array}$ & $\begin{array}{l}\text { NDMA } \\
(\mu \mathrm{g} / \mathrm{kg})\end{array}$ & $\begin{array}{c}\text { HIS } \\
(\mathrm{mg} / \mathrm{l})\end{array}$ & $\begin{array}{c}\text { TYR } \\
(\mathrm{mg} / \mathrm{l})\end{array}$ & $\begin{array}{c}\text { TRY } \\
(\mathrm{mg} / \mathrm{l})\end{array}$ & $\begin{array}{c}\text { PUT } \\
\text { (mg/l) }\end{array}$ & $\begin{array}{l}\text { CAD } \\
(\mathrm{mg} / \mathrm{l})\end{array}$ \\
\hline 1 & 12.58 & 4.25 & $<20$ & $<0.2$ & 0.00 & 85.83 & 0.25 & 1.96 & 0.47 \\
\hline 2 & 11.94 & 4.94 & $<20$ & 0.4 & 1.97 & 2.21 & 0.32 & 2.21 & 0.29 \\
\hline 3 & 13.28 & 5.30 & $<20$ & 0.3 & 0.04 & 82.77 & 0.55 & 3.95 & 3.53 \\
\hline 4 & 12.51 & 4.15 & $<20$ & 0.5 & 0.02 & 64.75 & 0.46 & 2.39 & 0.44 \\
\hline 5 & 12.73 & 4.26 & $<20$ & 0.3 & 0.03 & 57.70 & 0.16 & 2.60 & 0.22 \\
\hline 6 & 12.48 & 2.76 & 37.8 & $<0.2$ & 0.02 & 2.77 & 0.30 & 2.43 & 0.55 \\
\hline 7 & 12.07 & 5.16 & $<20$ & $<0.2$ & 0.03 & 58.67 & 0.16 & 3.04 & 0.41 \\
\hline 8 & 13.34 & 4.10 & 623 & $<0.2$ & 2.94 & 67.76 & 0.23 & 4.41 & 44.46 \\
\hline 9 & 9.97 & 3.05 & 380 & $<0.2$ & 0.10 & 84.03 & 0.18 & 4.63 & 26.71 \\
\hline 10 & 12.04 & 3.60 & 168.4 & 0.3 & 0.09 & 104.71 & 0.26 & 5.34 & 38.77 \\
\hline 11 & 13.59 & 4.55 & 75.61 & 0.3 & 0.51 & 76.79 & 0.17 & 4.30 & 10.28 \\
\hline 12 & 11.17 & 4.25 & 560 & $<0.2$ & 1.95 & 54.09 & 0.16 & 4.25 & 23.68 \\
\hline 13 & 10.83 & 4.17 & 222 & $<0.2$ & 0.07 & 3.64 & 0.18 & 2.71 & 21.36 \\
\hline 14 & 16.62 & 5.56 & 95.96 & 0.3 & 0.01 & 56.94 & 0.21 & 4.11 & 2.25 \\
\hline 15 & 10.95 & 3.90 & $<20$ & 0.3 & 0.02 & 52.57 & 0.22 & 2.04 & 0.76 \\
\hline 16 & 11.97 & 4.25 & 381 & 0.2 & 0.01 & 67.40 & 0.27 & 4.43 & 9.11 \\
\hline 17 & 12.63 & 4.55 & 319 & 0.2 & 0.01 & 38.94 & 0.15 & 1.73 & 6.15 \\
\hline 18 & 11.32 & 3.71 & 433 & $<0.2$ & 0.02 & 14.69 & 0.13 & 2.17 & 29.07 \\
\hline 19 & 11.17 & 4.38 & $<20$ & $<0.2$ & 0.02 & 0.26 & 0.00 & 2.64 & 0.22 \\
\hline 20 & 11.56 & 4.04 & $<20$ & 0.4 & 0.00 & 0.18 & 0.00 & 2.39 & 0.06 \\
\hline 21 & 13.97 & 5.26 & $<20$ & 0.5 & 0.00 & 1.10 & 0.30 & 2.40 & 0.11 \\
\hline 22 & 16.86 & 6.57 & $<20$ & 0.2 & 0.00 & 1.99 & 0.26 & 2.22 & 0.22 \\
\hline 23 & 14.16 & 5.44 & $<20$ & $<0.2$ & 0.00 & 1.15 & 0.09 & 1.88 & 0.41 \\
\hline 24 & 14.00 & 5.27 & $<20$ & 0.2 & 0.03 & 2.10 & 0.17 & 2.18 & 0.47 \\
\hline
\end{tabular}




\section{ZÁVĔR}

Pití piva přináší bezesporu řadu pozitiv. Pivo je vhodný nápoj pro tišení žízně, nebot obsahuje 92 \% vody. Pivo má díky obsahu $\mathrm{CO}_{2}$ občerstvující účinek, díky obsahu hořkých látek uklidňující účinek, má vysokou nutriční hodnotu vzhledem k obsahu sacharidů, aminokyselin, vitamínů a polyfenolů. Pivo má také dietetický význam, nebot stimuluje chut', trávení, má diuretické účinky. Důležitou vlastností je také vyvážené složení minerálů - pivo tedy může být součástí sodíkově chudých diet. Jak dokazuje naše studie, pivo je za podmínek moderovaného pití zdrojem mikronutrientů s příznivým účinkem na lidské zdraví.

Aby byla splněna výše popsaná tvrzení, musí být minimalizována možnost vzniku cizorodých látek. Sledování výskytu a zastoupení jednotlivých biogenních aminů v pivu je významné nejen z toxikologického, ale i z technologického hlediska. Studie výskytu biogenních aminů napomáhají monitorovat bezpečnost a kvalitu piva jako významné potraviny a jako indikátory mohou rovněž zpětně poukazovat na hygienu pivovarských provozů.

\section{PODĚKOVÁNÍ}

Tato práce byla vypracována za podpory MZE-Rg1014-Výzkum kvality a zpracování sladařských a pivovarských surovin.

\section{LITERATURA / REFERENCES}

Adlercreutz, H., Goldin, B. R., Gorbach, S. L., Höckerstedt, K. A. V., Vatanabe, S., Hämäläinen, E. K., Markkanen, M. H., Mäkelä, T. H., Wähälä, K. T., Hase, T. A., Fortis, T., 1995: Soybean phytoestrogen intake and cancer risc. J. Nutr., 125: 757-770.

Anlı, R. E., Vural, N., Yılmaz, S., Vural, H., 2004: The determination of biogenicamines in Turkish red wines. J. Food Comp. Anal., 17: 53-62.

Bamforth, C. W., 2004: In: Blackwell Science Ltd (ed) Health and Nutrition. Blackwell Publishing company, Oxford, UK.

Buňka, F., Budinský, P., Čechová, M., Drienovský, V., Pachlová, V., Matoulková, D., Kubáň, V., Buňková, L., 2012: Content of biogenic amines and polyamines in beers from the Czech Republic, J. Inst. Brew., 118(2): 213-216.

Corrao, C., Rubbiati, L., Bagnardi, V., Zambon, A., Poikolaine, K., 2000: Alcohol and coronary heart disease: a meta-analysis. Addiction, 95(10): 1505-1523.

ČSN EN 14122: Potraviny - Stanovení vitaminu B1 metodou HPLC, 1.1. 2004.

Dong, M. W., Lepore, J., Tarumoto, T., 1988: Factors affecting the ion-pair chromatogramy of water soluble vitamins. J. Chromat., 442: 81-95.

Emmerová M. et al., 2010: Pivo a zdraví. NAVA TISK, spol. s r.o., Plzeň.

Foti, P., Erba, D., Riso, P., Spadafranca, A., Criscuoli, F., Testolin, G., 2005: Comparison between daidzein and genistein antioxidant activity in primary and cancer lymphocytes. Arch. Biochem. Biophys., 433: 421-427.

Gasarasi, G., Kelgtermans, M., Verstrepen, K. J., van Roy, J., Delvaux, F. R., Derdelinckx, G., 2003: Occurrence of biogenic amines in beer: causes and proposal remedies. Monatssch. Brauwiss., 3/4: 58-63.

Gordon, M. H., 1996. Dietary antioxidants in disease prevention. Nat. Prod. Rep., 265, 273.

Greif, G., Greifová, M., Dvoran, J., Karovičová, J., Buchtová, V., 1998: Štúdium rastu a produkcie biogénnych amínov neiktorým mikroorganizmami za modelových podmienok (article in Slovak). Czech J. Food Sci., 17: 15-21.

Izquierdo-Pulido, M., Carceller-Rosa, J. P., Mariné-Font, A., Vidal-Carou, M. C., 1997: Tyramine formation by Pediococcus spp. during beer fermentation. J. Food Protect., 60: 831-836.

Izquierdo-Pulido, M., Font-Fabregas, J., Carceller-Rosa, J. M., Marine-Font, A., Vidal-Carou, M. C., 1996: Biogenic amine changes related to lactic acid bacteria during brewing. J. Food Protect., 59: 175-180.

Jurková, M., Čejka, P., Houška, M., Mikyška, A., 2013: Simultánní stanovení prenylflavanoidů a isoflavanoidů ve chmelu a pivu metodou HPLC-DAD: Studie aplikace homogenitu zeleného chmele v pivovarském procesu. Kvasny Prum. 59(2): 42-50.

Kalač, P., Kř́žzek, M., 2003: A Review of biogenic amines and polyamines in beer. J. Inst. Brew., 109(2): 123-128.

\section{CONCLUSIONS}

Beer drinking certainly brings a number of positive effects. Beer is a beverage suitable for relieving thirst because it contains $92 \%$ water. Due to the $\mathrm{CO}_{2}$ content beer has a refreshing effect, a calming effect due to the content of bitter substances, and has a high nutritional value due to the content of carbohydrates, amino acids, vitamins and polyphenols. Beer also has a dietary importance, as it stimulates appetite, digestion, and is diuretic. An important feature is a balanced mineral composition - beer can therefore be part of a low-sodium diet. As demonstrated by our study, under conditions of moderate drinking beer is a source of micronutrients with beneficial effect on human health.

To meet all these contentions, the possibility of the presence of contaminants must be minimized. Monitoring of the occurrence and amounts of biogenic amines in beer is important not only from toxicological but also from the technological point of view. Study of the occurrence of biogenic amines helps to monitor the safety and quality of beer as an important food and may serve as an indicator of the hygiene of brewing operations.

\section{ACKNOWLEDGEMENTS}

This work was performed with the support of MZE-RO1914 project "Research of the quality and processing of malting and brewing raw materials".

Kondo, K., 2003: Preventive effects of dietary beer on lifestyle-related diseases. Proceedings of the 29th EBC Congress, Dublin, Contribution 133.

Lorencová, E., Buňková, L., Matoulková, D., Dráb, V., Pleva, P., Kubáň, V., Buňka, F. 2012: Production of biogenic amines by lactic acid bacteria isolated from dairy products and beer. Int. J. Food Sci. Technol., 47: 2086-2091.

Loret, S., Deloyer, P., Dandrifosse, G., 2005: Levels of biogenic amines as a measure of the quality of the beer fermentation process: Data from Belgian samples. Food Chem., 89: 519-525.

Medjakovic, S., Jungbauer, A., 2008: Red clover isoflavones biochanin $A$ and formononetin are potentligands of the human aryl hydrocarbon receptor. J. Steroid Biochem. Mol. Biol., 108 (1,2): 171-177.

Mikyška, A., Hašková, D., Mikulíková, R., Anton, M., 2007: Influence of brewing raw materials and brewing technology on phytoestrogens content in beer. Proceedings of the 31st EBC Congress, Venice, Fachverlag Hans Carl, Nürnberg, 1199-1206.

Milligan, S. R., Kalita, J. C., Heyerick, A., Rong, H., De Cooman, L., De Keukeleire, D., 1999: Identification of a potent phytoestrogen in hops (Humulus lupulus L.) and beer. J. Clin. Endocrinol. Metab., 84(6): 2249-2252

Poli, A., Marangoni, F., Avogaro, A., Barba, G., Bellentani, S., Bucci, M., Cambieri, R., Catapano, A. L., Costanzo, S., Cricelli, C., de Gaetano, G., Di Castelnuovo, A., Faggiano, P., Fattirolli, F., Fontana, L., Forlani, G., Frattini, S., Giacco, R., La Vecchia, C., Lazzaretto, L., Loffredo, L., Lucchin, L., Marelli, G., Marrocco, W., Minisola, S., Musicco, M., Novo, S., Nozzoli, C., Pelucchi, C., Perri, L., Pieralli, F., Rizzoni, D., Sterzi, R., Vettor, R., Violi, F., Visioli, F., 2013: Moderate alcohol use and health: A consensus document. Nutr. Metab. Cardiovasc. Dis., 23(6): 487-504.

Preedy, R. W., 2009: Beer in health and disease prevention. Elsevier, ISBN 978-0-12-373891-2.

Shalaby, A. R., 1996: Significance of biogenic amines to food safety and human health. Food Res. Int., 29: 675-69.

Stevens, J. F., Taylor, A. W., Clawson, J. E., Deinzer, M. L., 1999: Fate of xanthohumol and related prenylflavonoids from hops to beer. J. Agric. Food. Chem., 47(6): 2421-2428.

Walters, C. L., Hart, R. J., Smith, P. L. R., 1983: Analysis of total N-nitroso compounds as a group by denitrosation to nitric oxide, with detection using chemiluminescence analyser. IARC Sci., 45, 295.

Zákon č. 110 / 1997 Sb. o potravinách a tabákových výrobcích a změně a doplnění některých souvisejících zákonů, v platném znění. 